Athens Journal of History - Volume 7, Issue 3, July 2021 - Pages 203-216

\title{
Byzantine Archaeological Remains in Beer Sheva, Israel
}

\author{
By Daniel Varga* E Svetlana Talis
}

\begin{abstract}
Beer Sheba in the Byzantine period was a large and important city in the province of Palestine Tertia. It served as an administrative, religious, and military center, and seat of the Roman military commander of Palestine. Beer Sheva is mentioned in many sources, including historical texts, epigraphic sources, and archaeological research. In recent years, following archaeological excavations conducted at the city's new transportation center have been uncovered Be'er Sheva's Byzantine residential neighborhoods. These excavations open a new window into the daily life of the city, in a way that did not exist before. The residential neighborhoods surrounded the city center to the north, east, and west and included buildings built on local loess soil and complexes dug within it. Industrial areas and large cemeteries with hundreds of tombs were located around the city. The state historical and archaeological research to date does not allow for a complete picture of the city in the Byzantine period. This article centralizes and summarizes most of the work on the subject to date and brings new insights to Byzantine Beer Sheva.
\end{abstract}

\section{Introduction - Historical, Literary, and Epigraphic Sources}

Beer Sheva, which is located in the northern Negev desert, appears in many sources: historical texts, epigraphic sources, and in archaeological research. The main historical source is the Notitia Dignitatum, a Roman imperial document from the beginning of the fourth century, the time of emperor Diocletian (284-305, $)^{1}$ which lists the senior officials and military units in the Roman Empire. This document states that a cavalry unit from Dalmatia was stationed in Be'er Sheva (Equites Dalmatae Illirian). Another important source is the Onomasticon of Eusebius, bishop of Caesarea and fourth-century church historian. In the chapter on Jesus, Eusebius describes Be'er Sheva as a large village with a large Roman garrison. ${ }^{2}$ In addition, the writings of the monk Jerome Million, who visited the area for an extended time in the late fourth and early fifth centuries, and the chronicles of the pseudo-bishop Eucherius of the fifth century, ${ }^{3}$ also add pieces of information about Late Roman and Byzantine Be'er Sheva.

The epigraphic evidence from Be'er Sheva includes two papyri from Nitzana dated to the beginning of the seventh century, burial inscriptions, and the geographical description of the Land of Israel in a mosaic from Madaba in the sixth century. It should be noted that the city of Be'er Sheva does not appear on the Peutinger map, which is a medieval replica of a geographical map from the Roman period.

"Archaeologist \& Researcher, Israel Antiquities Authority, Israel.

+Archaeologist \& Researcher, Israel Antiquities Authority, Israel.

1. All dates are AD.

2. S. Notley and Z. Safrai, Eusebius, Onomasticon (Leiden, 2005).

3. J. Wilkinson, Jerusalem Pilgrims before the Crusades (Warminster, 1977), 54. 
Another important epigraphic source, the "Be'er Sheva Edicts", shows the centrality of Be'er Sheva in the Byzantine military system; these tablets bear the names of the three provinces of Palestine (Prima, Secunda and Tertia) and the sums of money the residents are obliged to pay to the army. Three fragments of the slabs were found in Be'er Sheva, one by merchants in the $19^{\text {th }}$ century, ${ }^{4}$ another in secondary use inside the construction of a drainage canal from the Ottoman period ${ }^{5}$ and the third fragment in an excavation, also in secondary use, in a floor from the Early Islamic period. ${ }^{6}$

The tablets date to the $6^{\text {th }}$ century, to the time of Emperor Justinian (527-565) and mention that headquarters of the commander of the army stationed in Palestine (Dux Palestina) was in Be'er Sheva. ${ }^{7}$

Among the travelers who visited Be'er Sheva in the $19^{\text {th }}$ and early $20^{\text {th }}$ centuries, Robinson visited in 1838, Seetzen in 1855, Abel in 1903, Musil in 1907, and Woolly and Lawrence visited in $1914 .{ }^{8}$ All offer descriptions of the various remains.

\section{The Development of Be'er Sheva in Classical Times}

The Roman invasion of the northern Negev probably took place during the time of Vespasian and his sons Titus and Commodus (69-96), when the Romans built a line of fortresses between the Dead Sea in the east and Gaza to the west. ${ }^{9}$ This border area (Limes) led to the establishment of administrative, commercial, and settlement centers alongside the defensive ones. These sites were of different types including castles, observation towers, and various structures providing road services, such as guest houses. The main sites were (west to east): Menois, Birsama, Berosaba, Malatha and Engaddi (See Figure 1). In $106 \mathrm{CE}$, when the Romans annexed the Nabataean kingdom, the border crossed the Jordan and the "Flavi" limes, and the northern Negev lost the importance of its defensive value, although not completely. ${ }^{10}$ The nomadic population of the Negev forced the Romans to maintain forces even on the new home front and many localities, including Be'er Sheva, maintained their defensive character. Signs of this are the

4. F.M. Abel, "La Grotte de Moueileh," Revue Biblique 12 (1903): 429.

5. M. Avi-Yonah, "Other Studies," Quarterly of the Department of Antiquities of Palestine 10 (1944): 201.

6. I. Gilead and P. Fabian, "7000 Years Settlement: The Archaeological Remains of Beer Sheva from the Sixth Millennium BC. To the End of the First Millennium AD," in Beer Sheva: a Metropolis in the Making, ed. I. Gordon and M. Glickstein (Jerusalem, 2008), 319.

7. L. Di Segni, "The Beer Sheva Tax Edict Reconsidered in Light of a Newly Discovered Fragment," Scripta Classica Israelica XXIII (2004): 148-151.

8. C.L. Woolley and T.E. Lawrence, The Wilderness of Zin (London, 1914), 107-111.

9. M. Avi Yonah, Historical Geography of the Land of Israel (Jerusalem, 1962), 168.

10. Ibid. 
existence of walled settlements or, as in the case of Be'er Sheva, the establishment of an army camp.

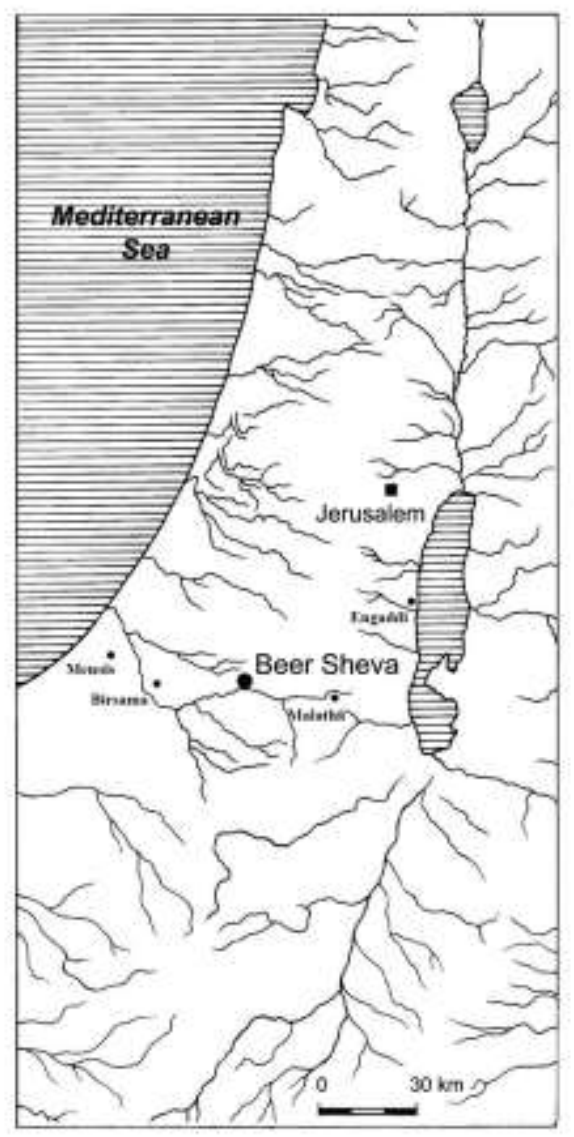

Figure 1. Map of Beer Sheva's Location Source: Daniel Varga.

It is not easy to get a clear picture of the nature and size of the city of Be'er Sheva from the ancient sources. Josephus Ben Matityahu in the first century calls Be'er Sheva a city (polis) and places it on the border of the desert ${ }^{11}$ and at the beginning of the $4^{\text {th }}$ century Eusebius calls it a very large village (Kome megiste.) ${ }^{12}$ At the end of that century Geronimus called Be'er Sheva a large village or town (Oppidum.) $)^{13}$ The picture obtained is that in the Late Roman period and the beginning of the Byzantine period Be'er Sheva was considered a civilian settlement, with an army camp, and not a military settlement. This is clearly seen in the writings of Eusebius, who states that within the settlement there is a military camp (phrourion), translated into Latin by Jeronimus "praesidium".

11. F. Josephus, Antiquitates Judaicae, trans. J. Henderson (London - Cambridge Mass, Loeb Classical Library, 1911), VIII, 13, 7.

12. Notley and Safrai, Eusebius, Onomasticon, 2005.

13. Wilkinson, Jerusalem Pilgrims before the Crusades, 1977, 54. 
In the sixth century, Be'er Sheva is presented as a city. The Madaba map depicts a rectangular shaped city on the southern border of Judea. It has several buildings, unlike the description of other cities in the Negev which appear on the map as castles or secondary cities with only one building. ${ }^{14}$ This description indicates the centrality of Be'er Sheva in the Negev. Despite the development of the city, it seems to have been under the administrative influence of Eleutheropolis (Beit Guvrin), according to the inscriptions on the cities' churches which indicate the foundation date according to the Eleutheropolis calendar.

Modern archaeological research on the city began in the 1950s, with the development of the modern Israeli city. Roman - Byzantine remains were unearthed in the southeastern part of the Old (Ottoman) city, around the Bedouin market, the central bus station, the Muslim cemetery, and Nahal Beer Sheva, as well as sporadic finds throughout the city (See Figure 2).

Archaeological excavations have revealed that in the fourth and fifth centuries CE, the city was one of the largest in the Land of Israel. ${ }^{15}$ The approximate area of the city, including the perimeter ring of cemeteries and industrial facilities, is about 200 hectares. The administrative, military, and religious center of Be'er Sheva is located in the area of the modern-day municipal market and covers about 50 hectares.

Remains of public buildings, bathhouses, monasteries, and churches were exposed in and around the city center. Remains of residential neighborhoods with wealthy houses were discovered east and north of the center. Nearby industrial areas with workshops and wineries were also uncovered. Large cemeteries with hundreds of lined cist graves developed around the city.

14. Avi-Yonah, The Madaba Mosaic Map (Jerusalem: Israel Exploration Society, 1954), 8087.

15. Gilead and Fabian, "7000 Years Settlement: The Archaeological Remains of Beer Sheva from the Sixth Millennium BC. To the End of the First Millennium AD," 2008; S. Talis, "Beer Sheva, Beith Eshel Street," Hadashot Arkheologiot 124 (2012); I. Peretz, "Beer Sheva, the Civic Center," Hadashot Arkheologiot 126 (2014); Varga and Nikolsky, "Beer Sheva, the Egged Bus Station," Hadashot Arkheologiot 125 (2013); Nikolski, "Beer Sheva, Shmaryahu Levine Street," 126 (2014). 


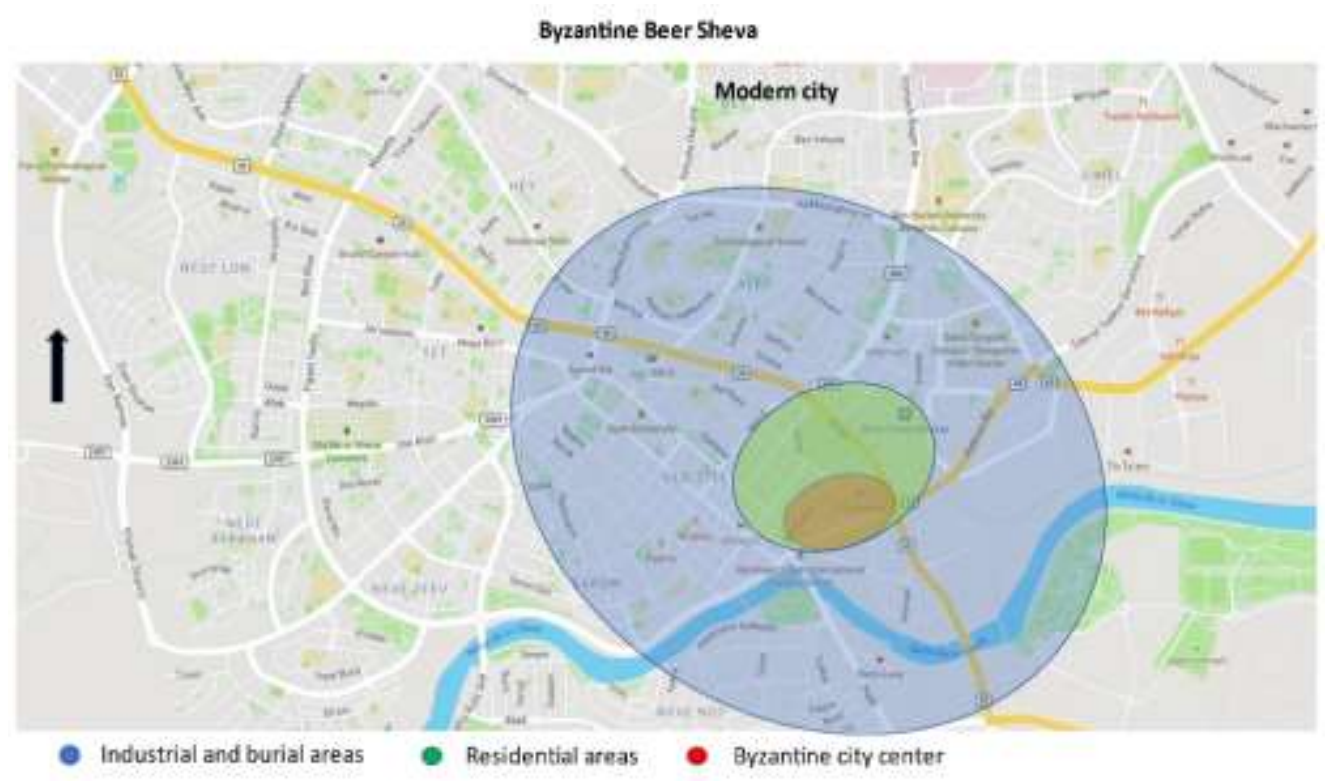

Figure 2. Byzantine Beer Sheva

Source: Daniel Varga.

\section{Churches and Monasteries}

Two churches were uncovered by Y. Israeli, the director of the Municipal Museum of the Negev and P. Fabian, on behalf of the Israel Antiquities Authority. Israeli dug in 1967 at the intersection of Eilat road and Sderot Rager ${ }^{16}$ and Fabian, in 1994 along the southeastern end of the Bedouin market. ${ }^{17} \mathrm{~A}$ monastery was uncovered in 1968 by R. Cohen excavating on behalf of the Department of Antiquities, in the municipal market, near and southwest of the intersection of Hebron and Eilat streets. ${ }^{18}$

According to Cohen, a mosaic floor was uncovered in the monastery building. The mosaic is decorated with geometric patterns set in the center, surrounded by grape tendrils forming medallions. Animals inhabited the medallions, the most prominent of which are the giraffe, tiger, snake, lion, wild boar, and hare. According to the style employed, the mosaic can be dated to the sixth century, like the mosaic floors at El Mahamam (Beit She'an), Shel, Beit Loyya, Maon, and others. ${ }^{19}$ In addition to the mosaic floor, Cohen describes

16. Y. Israeli, "News from the Archaeological Museum," Hadashot Arkheologiot 31 (1967): 30.

17. Fabian, "A Late Roman Military Camp at Beer Sheba: A New Discovery," Journal of Roman Archaeology Supplementary Series 14 (1995): 91-93.

18. R. Cohen, "Beer Sheva, The Bedouin Market," Hadashot Arkheologiot 27 (1968): 14-16.

19. R. Talgam, Mosaics of Faith (Jerusalem and Pennsylvania, 2014). 
additional rooms paved with stone slabs and ceramic vessels dating to the Byzantine period. ${ }^{20}$

In 1994, Fabian excavated a large church $(28 \times 41 \mathrm{~m})$, identified as the main church of Byzantine Be'er Sheva. The church, exposed in the southeast corner of the municipal market and northwest of the junction of Eilat and Hebron roads, has a rectangular plan divided in such a way that forms a cross. Originally the church floor was paved with mosaics bearing geometric patterns and birds. At a later stage of the structure all the mosaics, apart from the northern nave, were removed, and marble tiles were laid in their place.

According to an inscription incorporated in the northern nave mosaic with the date 552/553, according to the Eleutheropolis (modern Beit Guvrin) census, it seems that the church was built at the end of the $5^{\text {th }}$ century or in the first half of the 6th century. The church fell out of use during the $7^{\text {th }}$ century. Some of its rooms were used in the Early Islamic period for various purposes and it seems that at the end of the eighth century the building was abandoned. ${ }^{21}$

Another building, apparently a monastery, was uncovered in Be'er Sheva in 1991 in Horbat Matar in the modern Neve Zeev neighborhood, two kilometers west of the municipal market, near the northern bank of Nahal Be'er Sheva. ${ }^{22}$ The excavations revealed a 400-square-meter building constructed of dressed ashlars, some with remains of plaster and paint. It is suggested that a considerable part of the building was paved with mosaics, while other rooms were paved with stone slabs. Pillar bases, column fragments and a staircase indicate that the structure stood at least two stories high and probably served as a public building. The remains of the building include a gravestone with a Greek inscription engraved with the deceased's name: Saadala, and a date, according to the Eleutheropolis census, 537/538. ${ }^{23}$ Stone slabs with crosses, tabuns, and the ceramic assemblage date the building to the sixth century. At the beginning of the Early Islamic period the building was partially demolished and was converted into an agricultural farm.

\section{The Army Camp and the Issue of Location}

The outline of large building identified in a 1918 aerial photograph, was interpreted as military camp. In 1999 a rescue excavation carried out at the site situated between Rambam, Beit Eshel and Bnei Ein Harod streets revealed a

20. Cohen, "Beer Sheva, The Bedouin Market," 1968, 16.

21 Gilead and Fabian, "7000 Years Settlement: The Archaeological Remains of Beer Sheva from the Sixth Millennium BC. To the End of the First Millennium AD," 2008.

22 Gilead, Fabian and S. Rosen, "Hurvat Matar," Hadashot Arkheologiot 104 (1993).

23 Y. Ustinova and P. Figueras, "A New Greek Funerary Inscription from Beer Sheva," Atiqot 28 (1996): 167-170. 
system of rooms belonging, according to the excavators, to the internal structures of a camp.

Further salvage excavations conducted between Beit Eshel and Bnei Ein Harod streets (not yet published) showed scant remains dated to the Late Roman and Byzantine periods. These include a large structure with a courtyard surrounded by rooms. The identification of these remains as part of a military camp seems to stem from the identification of the outline seen in the aerial photograph and the mention of the Roman military commander. ${ }^{24}$

The edicts mentioning Be'er Sheva as the seat of the Palestinian army commander are the most important findings on the subject, although the exact location of the camp remains to be proven. So far, in excavations conducted in and around the rectangular compound identified as an army camp, no small finds of a military nature, such as weapons, a military workshop, clothing and defense details, etc. have been discovered. In our opinion the late-Byzantine Roman military camp mentioned in the sources has not yet been exposed.

\section{Bathhouses}

An impressive bathhouse was revealed in 2003 on Hebron Road, south of the municipal market. ${ }^{25}$ It seems to have operated from the third century until the end of the sixth or early seventh century. Several of the bath house rooms were exposed, including the tepidarium (the warm water room), the caldarium (the hot water room), water pools, the hypocaust built of square clay columns, and the heating structure. The maximum level of preservation of the walls was two courses, and most of the stones of the walls were apparently looted during the construction of the late $19^{\text {th }}$ century Ottoman city. The floors of the building were paved with marble slabs that were placed over a foundation of pottery sherds.

It is possible that in Compound C, about 100 meters north of the bathhouse, another bathhouse, much smaller than the previous one, operated from the Late Roman period. This is based on hypocaust fragments and sections of rooms plastered with hydraulic plaster that were exposed during the excavation of the site. $^{26}$

24. Fabian, "A Late Roman Military Camp at Beer Sheba: A New Discovery," 1995, 235240.

25. Gilead and Fabian, "7000 Years Settlement: The Archaeological Remains of Beer Sheva from the Sixth Millennium BC. To the End of the First Millennium AD," 2008.

26. Fabian and Gilead, "Beer Sheva: The C Compound," Hadashot Arkheologiot 122 (2010). 


\section{Residential Areas}

In recent years, following archeological excavations conducted in the city's new transportation center, Late Roman and Byzantine era residential neighborhoods have been recognized. These excavations offer new insights to the daily life in the period. Until now archaeological research in Be'er Sheva has mostly focused on the city's public buildings.

According to the findings so far, the residential neighborhoods surrounded the city center to the north, east, and west and included buildings built on local loess soil with complexes dug into it (See Figure 3). The walls of the buildings are made of a combination of stones and mud bricks.

Excavations at the Central Station ${ }^{27}$ revealed two residential buildings $(1,200$ sq.m.) built of chalk blocks and cobbles. Segmented walls, many times with only the foundations remaining, were built of flint, chalk and cobbles of various sizes. In the compacted loess soil, in the center of each yard, a round silo was dug in the ground, lined mainly with cobbles of various sizes, along with additional domestic agricultural installations were built.

From each courtyard, built on the surface, a staircase descended into underground spaces, basements, and semi-underground courtyards (See Figure 4). Two types of stairs were discovered at the site. The first type, the more elaborate, is built of dressed chalk. Apparently, these stairs led to the underground rooms. The second type of staircase is a combination of chalk, large cobbles, and flint. These stairs lead to additional courtyards and semiunderground rooms. The courtyards were open or had a roof made of perishable material, wooden beams and branches. Various agricultural facilities were found in the courtyards and in several the semi-underground rooms. These included crushing facilities, an oil press, and storage facilities. Identical finds were uncovered in additional excavations conducted on a smaller size, southeast and west of the central bus station. ${ }^{28}$ The finds inside the dwellings, which include a variety of pottery vessels, including vessels imported from Egypt, Cyprus, and North Africa, represent a wealthy and prosperous population, well connected with the Byzantine world.

Most of the pottery uncovered in the dwellings was of daily use: large storage vessels such as amphorae and jars of various types (about two-thirds of the "sack" type and one-third of the "Gaza" type), cooking pots, cooking jugs, jugs, and bowls. Most of the vessels were locally made and some are imported from Egypt, North Africa, and other places throughout the Eastern Mediterranean basin. The large number of oil candles (most of them of the "sandal" type), as well as the exposure of several lanterns, indicates work and possibly also living underground in poor light conditions or in the dark.

27. Varga and Nikolsky, "Beer Sheva, the Egged Bus Station," 2013.

28. Nikolski, "Beer Sheva, Shmaryahu Levine Street," 2014. 


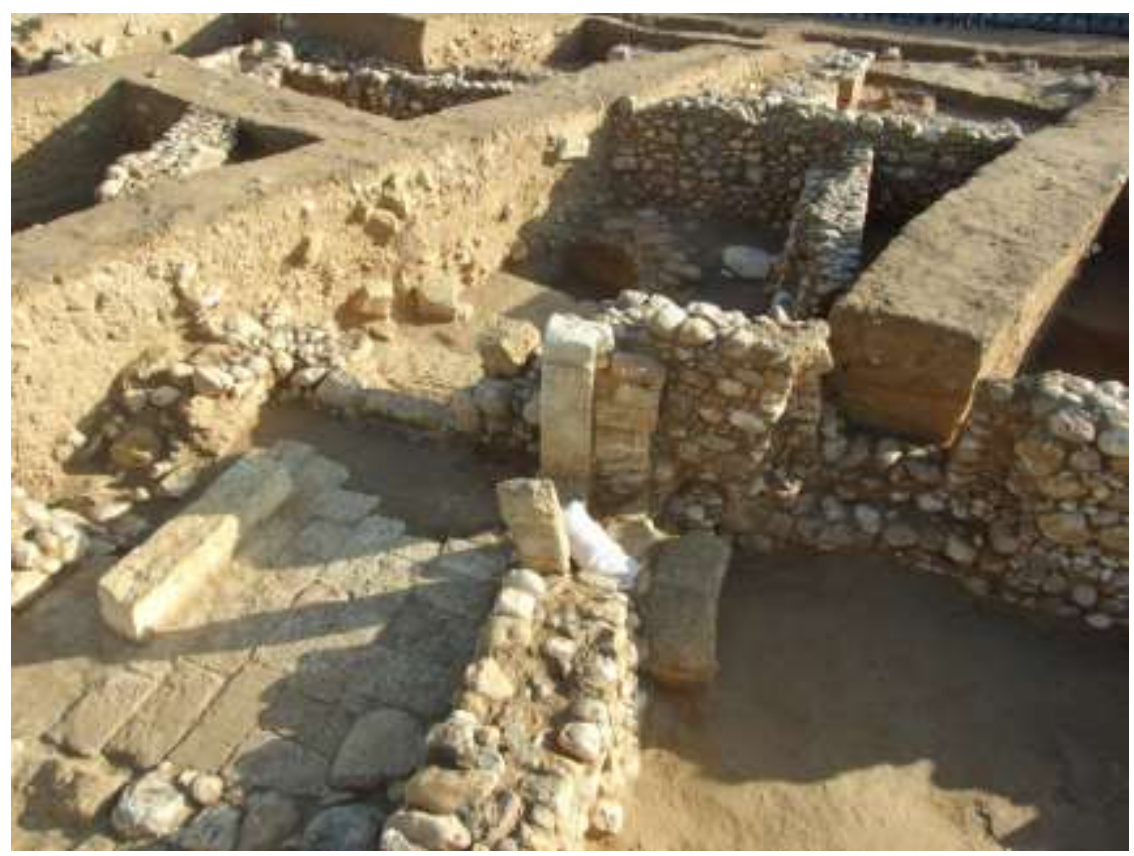

Figure 3. Dwellings at the Urban Transport Station Source: Assaf Peretz IAA.

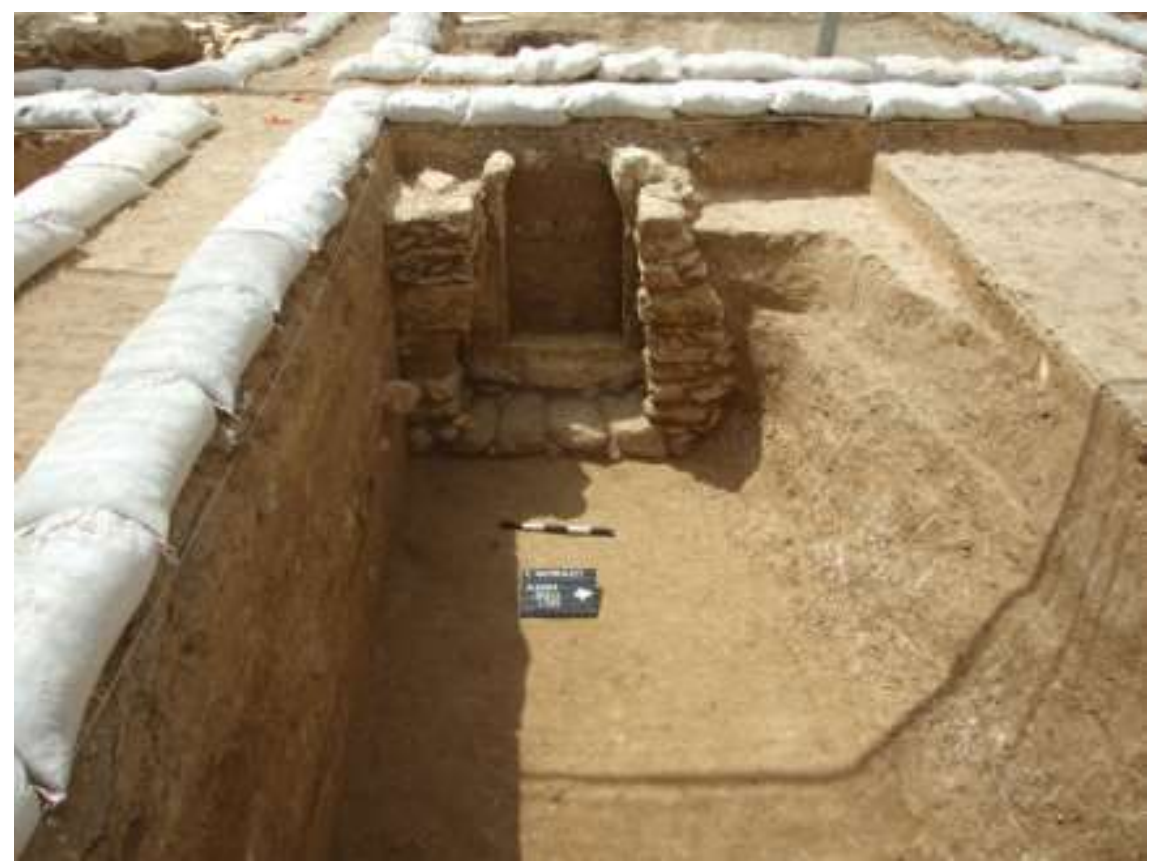

Figure 4. A Passage between two Subterranean Rooms Covered with an Arch Source: Assaf Peretz IAA. 


\section{Industry and Agriculture}

The remains of a pottery kiln were identified south of the Central Train Station but have not been excavated yet. Piles of pottery and household waste dating to the $5^{\text {th }}$ and $6^{\text {th }}$ centuries were found at the site.

The wine industry in Byzantine Be'er Sheva is represented by two excavations. In 1997, a winepress was uncovered on Nordau Street in the city civic center. The winepress included a rectangular pressing floor and a collecting vat. Near the winepress, segmented remains of other buildings, probably warehouses, were exposed. According to the relatively small size of the pressing floor, which was paved with stone tiles $(6 \times 3 \mathrm{~m})$, it was a cottage industry winepress. The walls were built of dressed limestone combined with cobbles. Grape seeds were found in a broken jar in the collecting vat. Another, larger, winepress was uncovered on the southern side of Be'er Sheva, south of the Nahal Be'er Sheva. ${ }^{29}$ The winepress was part of an agricultural farm established south of the Byzantine city of Be'er Sheva. A pressing floor $($ c. $7 \times 6.5 \mathrm{~m})$ with a squeezing device, a settling pit, and a collecting vat in the center were exposed. Most of the stone tiles that paved the trading floor were removed for secondary use. The outer walls of the winepress, built of ashlars, survived only to the height of a single course. Notably, based on the ceramics, this press seems to date somewhat later than the first one, extending into the Early Islamic period.

\section{Burials}

On the outskirts of Byzantine Be'er Sheva, a row of cemeteries was identified, a kind of circumference ring, defining the city's boundaries. Large cemeteries have been uncovered, and are still being uncovered, on all sides of the city.

The most common type of tomb is of the "lined cist tomb" type. This tomb consists of a rectangular cist dug in the loess soil. The cist sides are lined with rectangular chalk stone slabs.

One grave concentration in the area east of the Byzantine city ( 25 tombs) was uncovered in an excavation conducted prior to the construction of the Negev Shopping Mall. ${ }^{30}$ An excavation at the new Civic Center revealed 21 graves, and pieces of linen were discovered in one of the graves. ${ }^{31}$ In 2014, an excavation in the civic center revealed 78 graves in an area measuring roughly $40 \times 50 \mathrm{~m}$. To date, the highest density of graves was identified in this area. ${ }^{32}$ Five graves were

29. Y. Chaimi, "Beer Sheva, Southern Entrance," Hadashot Arkheologiot 120 (2008).

30. I. Govrin, "Beer Sheva," Hadashot Arkheologiot 115 (2001): 88-89.

31. Varga, "Beer Sheva, the Civic Center," Hadashot Arkheologiot 110 (1999): 131.

32. Peretz, "Beer Sheva, the Civic Center," 2014. 
excavated on Ben Zvi Street, near the civic center. ${ }^{33}$ An additional 30 graves were uncovered in excavations around the city center.

In an excavation in "Keren Towers", 13 tombs were excavated..$^{34}$ South of the Bedouin market, on the northern bank of Nahal Be'er Sheva, 60 tombs were excavated, most of which were built of ashlars. ${ }^{35}$ Inside two of them were lead coffins decorated with crosses. In several other cases, iron nails and wooden remains were discovered, suggesting the use of wood coffins.

During excavations conducted prior to the construction of the Central Bus Station, three burial chambers cut into the loess soil, five meters under the modern surface, and excavated. The burial chamber walls, lined with stone and plastered, were adorned with painted crosses and people in a prayer position. Many pottery vessels and coins, all dating to the Byzantine period, ${ }^{36}$ were found on the chamber floor. In the Israel Electric Company compound, southeast of the intersection of Rehovot Road through Eilat and Hebron Road, 18 lined cist graves were excavated, and another four were documented, but not excavated. Five tombs were exposed on the Hebron Road. ${ }^{37}$ More than 50 tombs were exposed, but not excavated south of Nahal Beer Sheva. ${ }^{38}$ In the Old City, west of Byzantine city center, tombs were identified on Weizmann Street, ${ }^{39}$ on Birnbaum Street, ${ }^{40}$ and on Herzl Street, and excavated on Hadassah Street. ${ }^{41}$

\section{The Agricultural Surrounds}

Discoveries of farms and agricultural installations in Be'er Sheva and its surroundings areas began in the 1950s. The development momentum of the early 1990s led to numerous archaeological excavations, revealed new finds of the agricultural hinterlands of Beer Sheva from the Byzantine period.42 The continuous expansion of the city in the 2000s resulted in new (still unpublished) excavations. In 2010 two Byzantine period farmhouses were excavated in the high-tech park north of the Be'er Sheva North train station. One farmhouse included nine rooms built around a central courtyard, a cistern, and two underground complexes, probably used as basements.

33 F. Sonntag, "Beer Sheva, Hadassah Street," Hadashot Arkheologiot 109 (1999): 137.

34. Nikolski, "Beer Sheva, Shmaryahu Levine Street," 2014.

35. A. Zelin, "Beer Sheva, Waissman Street," Hadashot Arkheologiot 113 (2001): 165.

36. Israeli, "News from the Archaeological Museum," 1967.

37. A. Barel, "Beer Sheva, Hebron Road," Hadashot Arkheologiot 113 (2001): 181.

38. I. Shuster, "Nahal Beer Sheva," Hadashot Arkheologiot 110 (1999): 109.

39. Zelin, "Beer Sheva, Waissman Street," Hadashot Arkheologiot 113 (2001), 180.

40. Sonntag, "Beer Sheva, Hadassah Street," Hadashot Arkheologiot 109 (1999): 138.

41. Sonntag, "Beer Sheva, Hadassah Street," 1999, 137

42. Gilead and Fabian, "7000 Years Settlement: The Archaeological Remains of Beer Sheva from the Sixth Millennium BC. To the End of the First Millennium AD," 2008, 21. 
The second farmhouse has three rooms, a cistern in the yard, and a large system of underground spaces, probably also used as basements. Stairs led from the building courtyards to an underground system. North of Be'er Sheva, in 2015, prior to the establishment of the Kalaniot neighborhood, part of a Byzantine farmhouse with a cistern, a building, and an underground cellar were unearthed. ${ }^{43}$ In 2015, the foundation course of a structure and a columbarium dated to the Byzantine period were exposed northwest of Be'er Sheva, adjacent to and south of the municipal zoo. The columbarium is round, divided into four cavities by two intersecting walls.

A building with several rooms and pottery vessels dating to the Byzantine period was identified (not excavated) in the Sara Valley industrial zone, southeast of Be'er Sheva. In 2015 part on an unpaved winepress with a collection vat lined with fieldstones was excavated adjacent and east of the building. ${ }^{44}$ In 2016 excavations were conducted prior to the construction of a new neighborhood on the southern outskirts of the city ${ }^{45}$ and some of the finds were dated to the Byzantine period. Degen's excavation exposed a building with enclosures (courtyards) and $50 \mathrm{~m}$ to the south, a circular columbarium. A residential building with ash and tabun remains was also excavated. Terraces were identified near the building. In the same area, a lime kiln with a combustion chamber preserved to a height of $1 \mathrm{~m}$ was uncovered.

\section{Conclusions}

Be'er Sheva in the Byzantine period was a large and important city in the province of Palestine Tertia. It served as an administrative, religious, military center, and seat of the Roman military commander of Palestine. The contrast between Be'er Sheva and the other cities of the Negev as they appear in the Madaba map emphasizes the special status of the city. Its importance is also evident in the public buildings which include at least two churches, one of which is a cathedral, municipal monasteries, and bathhouses. The churches built in the immediate vicinity of the city, such as Horbat Amra ${ }^{46}$ and Horbat Karkur Illit ${ }^{47}$ emphasize the centrality of Be'er Sheva at that time.

Houses of the wealthy, discovered on the outskirts of the Byzantine city, indicate a prosperous population that lived and worked there.

It can be assumed that its markets traded in a variety of products brought from the farmhouses in the agricultural hinterland of the city. Moreover, many

43. D. Degan, "Beer Sheva," Hadashot Arkheologiot 128 (2016).

44. F. Kobrin, "Emek Sarah," Hadashot Arkheologiot 128 (2016).

45. Degan, "Beer Sheva," Hadashot Arkheologiot 128 (2016): 135.

46. G. Tahal, "Horvat Amra," Hadashot Arkheologiot 108 (1998): 167-169.

47. P. Figueras, Horvat Karkur Illit. (Beer Sheva, 2004). 
imported vessels (pottery and glass vessels) unearthed in various excavations throughout the city, indicate trade ties with areas from all over the province of Palestine and the Byzantine Empire.

Many cemeteries and industrial buildings surrounded surrounded the city in all directions. Small satellite settlements, monasteries, and agricultural farms were built around the city. ${ }^{48}$

Archaeological remains indicate that the settlement survived the Arab invasion of $636 \mathrm{AD}$, throughout at least the $8^{\text {th }}$ century AD. Pottery was found in Byzantine buildings in Be'er Sheva from the Umayyad period about 640-750 and this confirms the knowledge that the settlement in the city continues in the early Muslim period.

The condition of the historical and archeological research of Be'er Sheva so far does not enable a complete picture of the city in the Byzantine period. We hope that this study will serve as a starting point for future comprehensive studies focusing on "the large picture" and not just on rescue excavations, which, despite their importance, provide only data of the specific locale.

In addition, we hope that this study will also serve as a starting point for future comprehensive studies, which will focus on producing a large image, and not just on rescue excavations, which, despite their importance, provide only point data.

\section{Bibliography}

Abel, F.M. "La Grotte de Moueileh." [The Great Moueileh.] Reoue Biblique 12 (1903).

Avi-Yonah, M. "Other Studies." Quarterly of the Department of Antiquities of Palestine 10 (1944): 200-219.

Avi-Yonah, M. The Madaba Mosaic Map. Jerusalem: Israel Exploration Society, 1954. Avi Yonah, M. Historical Geography of the Land of Israel. Jerusalem, 1962. (Hebrew).

Barel, A. "Beer Sheva, Hebron Road." Hadashot Arkheologiot 113 (2001): 181. (Hebrew).

Chaimi, Y. "Beer Sheva, Southern Entrance." Hadashot Arkheologiot 120 (2008). (Hebrew).

Cohen, R. "Beer Sheva, The Bedouin Market." Hadashot Arkheologiot 27 (1968): 86-87. (Hebrew).

Dagan, D. "Beer Sheva." Hadashot Arkheologiot 128 (2016): 135. (Hebrew).

Di Segni, L. "The Beer Sheva Tax Edict Reconsidered in Light of a Newly Discovered Fragment." Scripta Classica Israelica XXIII (2004): 132-158.

48. Tahal, "Horvat Amra," 1998: 167-169; N. Paran, "Nahal Fehar," Hadashot Arkheologiot 121 (2009); Fabian and I. Masarwah, "Beer Sheva, Ramot C Neighborhood," Hadashot Arkheologiot (2003): 104, Fabian and G. Seri, "Beer Sheva, Ramot D Neighborhood," Hadashot Arkheologiot 115 (2003): 104-105; Figueras, Horvat Karkur Illit, 2004; Sonntag, "Beer Sheva, Enriette Sold Street," Hadashot Arkheologiot 113 (2001): 180; N. Paran, "Beer Sheva, Ramot B," Hadashot Arkheologiot 111 (2000): 108-109. 
Vol. 7, No. 3 Varga \& Talis: Byzantine Archaeological Remains in Beer Sheva, Israel

Fabian, P. "A Late Roman Military Camp at Beer Sheba: A New Discovery." Journal of Roman Archaeology Supplementary Series 14 (1995): 235-240.

Fabian, P. and I. Masarwah. "Beer Sheva, Ramot C Neighborhood." Hadashot Arkheologiot (2003): 104-115. (Hebrew).

Fabian, P. and G. Seri. "Beer Sheva, Ramot D Neighborhood." Hadashot Arkheologiot 115 (2003): 105. (Hebrew).

Fabian, P. and I. Gilead. "Beer Sheva: The C Compound." Hadashot Arkheologiot 122 (2010): 115-117. (Hebrew).

Figueras, P. Horvat Karkur Illit. Beer Sheva, 2004.

Gilead, I., P. Fabian and S. Rosen. "Hurvat Matar." Hadashot Arkheologiot 104 (1993): 88-89. (Hebrew).

Gilead, I. and P. Fabian. "7000 Years Settlement: The Archaeological Remains of Beer Sheva from the Sixth Millennium BC. To the End of the First Millennium AD." In Beer Sheva: a Metropolis in the Making, edited by I. Gordon and M. Glickstein, 303-331. Jerusalem, 2008.

Govrin, I. "Beer Sheva." Hadashot Arkheologiot 115 (2001): 88-89. (Hebrew).

Israeli Y. "News from the Archaeological Museum." Hadashot Arkheologiot 31 (1967): 28. (Hebrew).

Josephus, F. Antiquitates Judaicae. [Antiquities of the Jews.] Translated by J. Henderson. London - Cambridge Mass, Loeb Classical Library, 1911.

Kobrin, F. "Emek Sarah." Hadashot Arkheologiot 128 (2016). (Hebrew).

Nikolski, V. "Beer Sheva, Shmaryahu Levine Street." 126 (2014). (Hebrew).

Notley, S. and Z. Safrai. Eusebius, Onomasticon. Leiden, 2005.

Paran, N. "Beer Sheva, Ramot B." Hadashot Arkheologiot 111 (2000): 108-109. (Hebrew).

Paran, N. "Nahal Fehar." Hadashot Arkheologiot 121 (2009). (Hebrew).

Peretz, I. "Beer Sheva, the Civic Center." Hadashot Arkheologiot 126 (2014). (Hebrew).

Shuster, I. "Nahal Beer Sheva." Hadashot Arkheologiot 110 (1999): 109. (Hebrew).

Sonntag, F. "Beer Sheva, Hadassah Street." Hadashot Arkheologiot 109 (1999): 137. (Hebrew).

Sonntag, F. "Beer Sheva, Ben Zvi Street Street." Hadashot Arkheologiot 109 (1999): 138. (Hebrew).

Sonntag, F. "Beer Sheva, Enriette Sold Street." Hadashot Arkheologiot 113 (2001): 180.

Tahal, G. "Horvat Amra." Hadashot Arkheologiot 108 (1998): 167-169. (Hebrew).

Talgam, R. Mosaics of Faith. Jerusalem and Pennsylvania, 2014.

Talis, S. "Beer Sheva, Beith Eshel Street." Hadashot Arkheologiot 124 (2012). (Hebrew).

Ustinova, Y. and P. Figueras P. "A New Greek Funerary Inscription from Beer Sheva." Atiqot 28 (1996): 167-170.

Varga, D. "Beer Sheva, the Civic Center." Hadashot Arkheologiot 110 (1999): 131. (Hebrew).

Varga, D. and V. Nikolsky. "Beer Sheva, the Egged Bus Station." Hadashot Arkheologiot 125 (2013). (Hebrew).

Wilkinson, J. Jerusalem Pilgrims before the Crusades. Warminster, 1977.

Woolley, C.L. and T.E. Lawrence. The Wilderness of Zin. London, 1914.

Zelin, A. "Beer Sheva, Waissman Street." Hadashot Arkheologiot 113 (2001): 180. (Hebrew). 